\title{
PREDICTING THE NEED FOR VENTILATORY SUPPORT IN ORGANOPHOSPHORUS COMPOUND POISONING
}

\author{
Peddi Bhaskar', P. Rajendra Prasad², P. Srikanth Reddy ${ }^{3}$ \\ ${ }^{1}$ Associate Professor, Department of Medicine, KMC/MGM Hospital, Warangal, Telangana. \\ ${ }^{2}$ Associate Professor, Department of Medicine, KMC/MGM Hospital, Warangal, Telangana. \\ 3Postgraduate, Department of Medicine, KMC/MGM Hospital, Warangal, Telangana.
}

\section{ABSTRACT}

Organophosphorus compound poisoning is a major health problem not only in developing countries, but also in western countries. ${ }^{1}$ Hospital-based statistics suggest that nearly half of the admissions to emergency with acute poisoning are due to organophosphorus compound poisoning. ${ }^{2}$

\section{MATERIALS AND METHODS}

The study was conducted on 100 patients who were diagnosed to have consumed organophosphorus compound poison admitted in M.G.M Hospital, Warangal, from April 2013 to May 2014 who were admitted within 24 hours of consumption of the poison.

\section{RESULTS}

100 patients diagnosed to have consumed organophosphorus compound poison were studied in relationship to the need for ventilatory support. In the total target study of 100 patients, 36 patients required ventilatory support.

\section{DISCUSSION}

Acute organophosphorus compound poisoning is one of the most frequent poisonings encountered in M.G.M Hospital. The major cause of poisoning in the present study was attempted suicides (100\%).

\section{CONCLUSION}

The factors, which predicted the need for ventilatory support in organophosphorus compounds poisoning in our study of 100 patients. The presence of higher fasciculation score $(\geq 4)$ was associated with the higher need for ventilatory support. A GCS score $\leq 10$ was significantly associated with an increased need of ventilatory support.

\section{KEYWORDS}

Organophosphorus Poisoning, Ventilator, Atropine.

HOW TO CITE THIS ARTICLE: Bhaskar P, Prasad PR, Reddy PS. Predicting the need for ventilatory support in organophosphorus compound poisoning. J. Evolution Med. Dent. Sci. 2016;5 (66):4716-4721, DOI: 10.14260/jemds/2016/1075

\section{INTRODUCTION}

Organophosphorus compound poisoning is a major health problem not only in developing countries, but also in western countries. ${ }^{1}$ Hospital-based statistics suggest that nearly half of the admissions to emergency with acute poisoning are due to organophosphorus compound poisoning. ${ }^{2}$

Organophosphorus compounds were first discovered more than 100 years ago are at present the predominant group of insecticides employed globally for pest control. ${ }^{3}$ Organophosphorus compound poisonings are found to be a leading cause of death in agricultural countries globally. ${ }^{4-5}$ Organophosphorus compounds poisoning affects globally approximately 3 million population and causes 2,00,000 deaths annually, most of these occur in developing countries. ${ }^{6}$

Organophosphorus compounds are easily available as insecticides in shops and have resulted in a gradual increase in suicidal and accidental poisoning.

Financial or Other, Competing Interest: None.

Submission 21-07-2016, Peer Review 02-08-2016,

Acceptance 05-08-2016, Published 17-08-2016.

Corresponding Author:

Dr. Peddi Bhaskar,

Flat No. 303,

Door No. 13-1-133,

Sai Towers, Matwada,

Warangal District, Telangana.

E-mail: bhaskar_peddi2003@yahoo.co.in

DOI: 10.14260/jemds/2016/1075
Nearly $90 \%$ of the poisoning are suicidal with a fatality rate of $>10 \%$. $8-10 \%$ accidental and $<1 \%$ homicidal. Occupational exposure accounts for $1 / 5^{\text {th }}$ of accidental poisoning with fatalities of $<1 \%{ }^{7}$

The organophosphorus compounds are the organic derivatives of phosphorous-containing acids. The phosphonate, which are organic derivatives of phosphoric acid are not used as insecticides, but are used as chemical warfare agents. Organophosphorus compounds combine with esteratic sites of acetyl cholinesterase that is phosphorylated and phosphorylated esteratic sites undergo hydrolysis. The phosphorylated enzyme is inactive and thus unable to hydrolyse acetylcholine. The biological effects of organophosphorus compound are as a result of accumulation of endogenous acetylcholine at sites of cholinergic transmission. This causes disruption of transmission of nerve impulses in both peripheral and central nervous system. Most organophosphorus compounds are readily absorbed through respiratory, oral mucous membrane, GIT mucous, and through intact skin as they are lipid soluble. This binding is irreversible except with early pharmacological intervention. ${ }^{8}$

The diagnosis is based on the history of exposure and features of cholinergic overactivity. ${ }^{9}$ The treatment includes atropine or glycopyrrolate, which acts as a physiological antidote, PAM, which help in reactivating the enzyme. 
Complications like respiratory failure, CNS depression, and ventricular arrhythmias should be anticipated and treated. The early causes of death in organophosphorus compound poisonings are chiefly related to ventricular arrhythmias, CNS depression, seizures, or respiratory failure due to excessive bronchial secretions, bronchospasm, pulmonary oedema, aspiration of gastric contents, paralysis of respiratory muscles, or apnoea associated with depression of the medullary respiratory center. ${ }^{10}$ Late mortality is associated with respiratory failure ${ }^{11,12}$ and infections like pneumonia, septicaemia, or complications related to mechanical ventilator and intensive care management. ${ }^{13}$ This study will help us to identify the factors, which help in predicting the need for ventilatory support in a patient with OP poisoning.

\section{MATERAILS AND METHODS}

The study was conducted on 100 patients who were diagnosed to have consumed organophosphorus compound poison admitted in M.G.M. Hospital, Warangal, from April 2013 to May 2014, who were admitted within 24 hours of consumption of the poison. The included patients were intensively monitored for signs of respiratory insufficiencies like respiratory rate of $>30$ breaths/minute, accessory muscles of respiration in action, 02 saturation $<90 \%$, Arterial Blood Gas Analysis (ABG) - PaO2 <50 mmHg, PCO2 >50 mmHg. If any one or more are present, the decision for mechanical ventilator was taken. Bradycardia was defined as $<60$ beats/minute.

Patients with concomitant illness or conditions likely to alter the respiratory effort due to organophosphorus compound poisoning, patients with double poisoning with other poisons, those with chronic lung disease, and those treated outside were excluded from the study.

Based on the factors that influence the need for ventilatory support, the severity of organophosphorus compound poisoning was graded as mild, moderate, and severe poisoning.

\section{Mild Poisoning includes}

- Normal level of consciousness. (Score of 12-15 by Glasgow coma scale (GCS)).

- Pupil size $\geq 4 \mathrm{~mm}$.

- Fasciculation score 0-1.

\section{Moderate Poisoning includes}

- $\quad$ Mild alteration in level of consciousness. (Score of 8-11 by GCS).

- Pupil size 2-3 mm.

- Fasciculation score 2-4.

\section{Severe Poisoning includes}

- $\quad$ Stupor/Coma (GCS 7 or less).

- Pinpoint pupil (1 $\mathrm{mm}$ or less).

- Presence of convulsions.

- Fasciculation score 5 or more.

- Signs of respiratory insufficiency.

Grading of fasciculation was done by giving 1 point depending on the presence of fasciculations each to the anterior chest, posterior chest, anterior abdomen, posterior abdomen, right thigh, left thigh, right leg, left leg, right arm, and left arm. Patients with concomitant illness or conditions likely to alter the respiratory effort due to organophosphorus compound poisoning, patients with double poisoning with other poisons, those with chronic lung disease, and those treated outside were excluded from the study.

Based on the factors that influence the need for ventilatory support, the severity of organophosphorus compound poisoning was graded as mild, moderate, and severe poisoning.

\section{Mild Poisoning Includes}

- Normal level of consciousness (Score of 12-15 by Glasgow coma scale (GCS)).

- Pupil size $\geq 4 \mathrm{~mm}$.

- Fasciculation score 0-1.

\section{Moderate Poisoning Includes}

- $\quad$ Mild alteration in level of consciousness. (Score of 8-11 by GCS).

- $\quad$ Pupil size 2-3 mm.

- Fasciculation score 2-4.

\section{Severe poisoning includes}

- Stupor/Coma (GCS 7 or less).

- $\quad$ Pinpoint pupil (1 $\mathrm{mm}$ or less).

- Presence of convulsions.

- Fasciculation score 5 or more.

- Signs of respiratory insufficiency.

Grading of fasciculation was done by giving 1 point depending on the presence of fasciculations each to the anterior chest, posterior chest, anterior abdomen, posterior abdomen, right thigh, left thigh, right leg, left leg, right arm, and left arm.

\section{RESULTS}

100 patients diagnosed to have consumed organophosphorus compound poison were studied in relationship to the need for ventilatory support. In the total target study of 100 patients, 36 patients required ventilatory support.

\begin{tabular}{|c|c|c|c|c|}
\hline $\begin{array}{c}\text { Age in } \\
\text { Years } \\
\text { (N=100) }\end{array}$ & $\begin{array}{c}\text { Number of } \\
\text { Patients } \\
\text { are } \\
\text { Presented }\end{array}$ & $\begin{array}{c}\text { Number of } \\
\text { Patients } \\
\text { with } \\
\text { Ventilation }\end{array}$ & $\begin{array}{c}\text { P } \\
\text { Value }\end{array}$ & $\begin{array}{c}\text { Odds Ratio } \\
\text { Ventilation }\end{array}$ \\
\hline $13-20$ & $22(22 \%)$ & $8(8 \%)$ & $\begin{array}{c}P>0.0 \\
5\end{array}$ & 1.02 \\
\hline $21-30$ & $58(58 \%)$ & $22(22 \%)$ & 0.655 & 1.22 \\
\hline$>30$ & $20(20 \%)$ & $6(6 \%)$ & 0.61 & 0.71 \\
\hline \multicolumn{5}{|c|}{ Table 1: Age Distribution with Ventilation } \\
\hline
\end{tabular}

Majority of the patients who were ventilated were in the age group of 21-30 (58\%), but this was not statistically significant $(\mathrm{P}>0.05)$

\begin{tabular}{|c|c|c|c|}
\hline Sex & $\begin{array}{c}\text { Number of } \\
\text { Presented } \\
\text { (n=100) }\end{array}$ & $\begin{array}{c}\text { Number of } \\
\text { Patients } \\
\text { with } \\
\text { ventilation } \\
\text { (n=18) }\end{array}$ & \multirow{2}{*}{ P Value } \\
\hline Male & $60(60 \%)$ & $26(26 \%)$ & \multirow{2}{*}{$\mathrm{P}=0.0855$} \\
\hline Female & $40(40 \%)$ & $10(10 \%)$ & \\
\hline \multicolumn{2}{|c|}{ Table 2: Sex Distribution with Ventilation } \\
\hline
\end{tabular}

Male patients were 60 (60\%) and females were 40 (40\%). 
The gender distribution among patients ventilated is not statistically significant with sex $(\mathrm{P}>0.05)$.

\begin{tabular}{|c|c|c|c|c|}
\hline 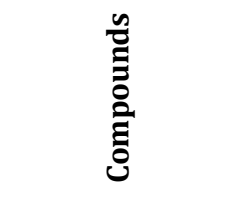 & 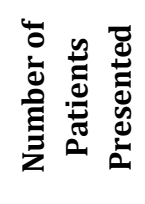 & 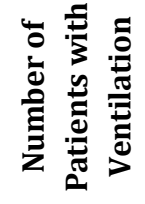 & 党 & 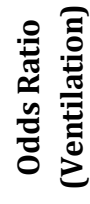 \\
\hline Acephate & $8(8 \%)$ & - & - & - \\
\hline Triazophos & $2(2 \%)$ & - & - & - \\
\hline Dimethoate & $2(2 \%)$ & - & - & - \\
\hline Malathion & $2(2 \%)$ & - & - & - \\
\hline Monocrotophos & $26(26 \%)$ & $13(13 \%)$ & 0.099 & 1.47 \\
\hline Temephos & $2(2 \%)$ & $2(2 \%)$ & 0.617 & - \\
\hline Chlorpyrifos & $26(26 \%)$ & $13(13 \%)$ & 0.099 & 1.47 \\
\hline Dichlorvos & $16(16 \%)$ & $6(6 \%)$ & $>.05$ & 0.72 \\
\hline Quinophos & $4(4 \%)$ & - & - & - \\
\hline Phorate & $10(10 \%)$ & $2(2 \%)$ & 0.32 & 0.28 \\
\hline Parathion & $2(2 \%)$ & - & - & - \\
\hline \multicolumn{5}{|c|}{ Table 3: Relationship of Compounds } \\
\hline
\end{tabular}

Of the patients who consumed organophosphorus poison, monocrotophos and chlorpyrifos were the most commonly consumed poisons ( 26 in each group). $50 \%$ patients who consumed these compounds required ventilatory support. Patients who consumed Dichlorvos and Phorate were least likely to receive ventilatory support. Hence, statistically patients who consumed monocrotophos and chlorpyrifos are 1.47 times more likely to receive ventilation.

\begin{tabular}{|c|c|c|c|c|}
\hline 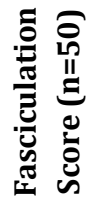 & 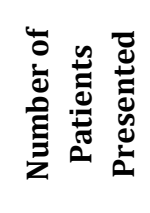 & 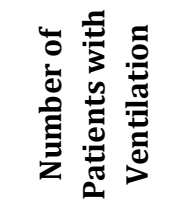 & $\begin{array}{l}0 \\
\frac{\pi}{2} \\
2\end{array}$ & 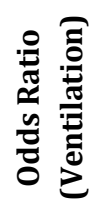 \\
\hline 0 & $28(28 \%)$ & $6(6 \%)$ & 0.067 & 0.38 \\
\hline $1-3$ & $40(40 \%)$ & $10(10 \%)$ & 0.0885 & 0.44 \\
\hline \multirow[t]{2}{*}{$\geq 4$} & $32(32 \%)$ & $20(20 \%)$ & $\begin{array}{c}0.0017 * \\
*\end{array}$ & 5.42 \\
\hline & ** highly & $\begin{array}{c}\text { Statistically } \\
\text { significant }\end{array}$ & & \\
\hline
\end{tabular}

Generalised fasciculations was another conspicuous feature in $72 \%$ of cases in this study.

Patients with fasciculation score of $\leq 3$ are less likely to receive ventilation. The patients with a fasciculation score $\geq 4$ are 5.42 times more likely to receive ventilation.

\begin{tabular}{|c|c|c|c|c|}
\hline 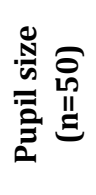 & 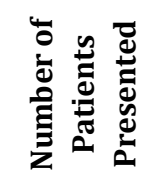 & 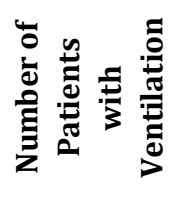 & $\frac{0}{\stackrel{0}{\pi}}$ & 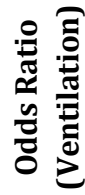 \\
\hline$\leq 1$ & $28(28 \%)$ & $20(20 \%)$ & 0.144 & 1.61 \\
\hline$\geq 2$ & $52(52 \%)$ & $16(16 \%)$ & 0.144 & 0.62 \\
\hline
\end{tabular}

Patients with pupil size $\leq 1 \mathrm{~mm}$ are 1.61 times more likely to require ventilation as compared to the patients with pupil size $\geq 2 \mathrm{~mm}$. This finding is not statistically significant.

\begin{tabular}{|c|c|c|c|c|}
\hline 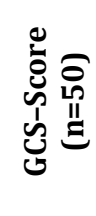 & 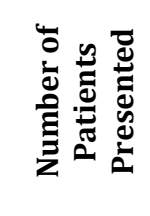 & 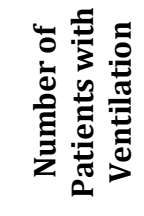 & $\underbrace{0}_{0}$ & 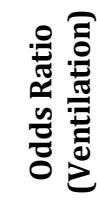 \\
\hline$\leq 10$ & $26(26 \%)$ & $22(22 \%)$ & $\mathrm{P}<0.001^{* *}$ & 23.57 \\
\hline $11-15$ & $74(74 \%)$ & $14(14 \%)$ & $\mathrm{P}<0.001^{* *}$ & 0.04 \\
\hline
\end{tabular}

Seventy four (74\%) patients had a GCS score of $11-15$, out of these 14 (18.9\%) patients required ventilatory support. Ventilatory support was required by $84.6 \%$ of patients who had a GCS score $\leq 10$. Hence, patients with GCS score $\leq 10$ are 23.57 times more likely to receive ventilation when compared to the patients with GCS score 11-15.

\begin{tabular}{|c|c|c|c|c|}
\hline 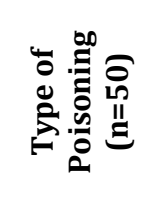 & 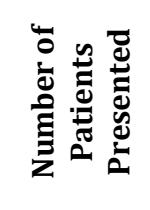 & 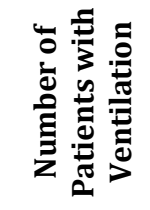 & 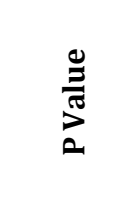 & 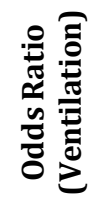 \\
\hline Mild & $46(46 \%)$ & $10(10 \%)$ & $0.007^{*}$ & 0.30 \\
\hline Moderate & $30(30 \%)$ & $10(10 \%)$ & $>.05$ & 0.85 \\
\hline Severe & $24(24 \%)$ & $16(16 \%)$ & $0.0006^{*}$ & 5.60 \\
\hline
\end{tabular}

Ten $(21.7 \%)$ of the patients with mild poisoning and $33.3 \%$ of the patients with moderate poisoning required ventilatory support. In contrast, $66.6 \%$ of the patients with severe poisoning required ventilation. Hence, patients with severe poisoning were 5.6 times more likely to receive ventilation.

\begin{tabular}{|c|c|c|}
\hline $\begin{array}{c}\text { Time Lag } \\
\text { (n=100) }\end{array}$ & $\begin{array}{c}\text { Number of } \\
\text { Patients } \\
\text { Presented }\end{array}$ & $\begin{array}{c}\text { Number of Patients } \\
\text { with Ventilation }\end{array}$ \\
\hline$<4$ hrs. & $4(4 \%)$ & - \\
\hline$\geq 4$ hrs. & $96(96 \%)$ & $36(36 \%)$ \\
\hline $\begin{array}{c}\text { Table 8: Relationship between Time Lag of Consumption of } \\
\text { Poison and Admission to the Hospital with Ventilatory } \\
\text { Support }\end{array}$ \\
\hline \multicolumn{3}{|c|}{} \\
\hline
\end{tabular}


Of the patients admitted to the hospital $\geq 4$ hours after consumption of poison, $36 \%$ required ventilatory support. In comparison, patients admitted $<4$ hours of consumption, did not require ventilatory support. This finding is statistically significant.

\begin{tabular}{|c|c|c|c|}
\hline $\begin{array}{c}\text { Pulse rate } \\
(\mathbf{n = 1 0 0 )} \\
\text { Beats/Mins }\end{array}$ & $\begin{array}{c}\text { Number of } \\
\text { Patients } \\
\text { Presented }\end{array}$ & $\begin{array}{c}\text { Number of } \\
\text { Patients with } \\
\text { Ventilation }\end{array}$ & $\begin{array}{c}\text { Significance } \\
\text { (P Value) }\end{array}$ \\
\hline$\leq 60$ & $6(6 \%)$ & $2(2 \%)$ & $\mathrm{P}>0.05$ \\
\hline $61-70$ & $62(62 \%)$ & $26(26 \%)$ & 0.136 \\
\hline$\geq 71$ & $32(32 \%)$ & $8(8 \%)$ & 0.126 \\
\hline \multicolumn{4}{|c|}{ Table 9: Relationship of Pulse Rate with Ventilation } \\
\hline
\end{tabular}

Bradycardia was present in $6 \%$ of the cases in the present study. There is no statistical association between pulse rate and ventilation.

\begin{tabular}{|c|c|c|c|c|}
\hline 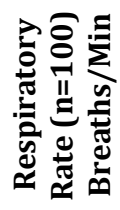 & 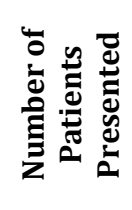 & 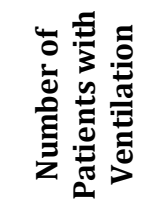 & 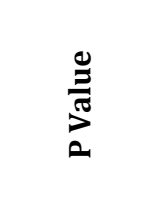 & 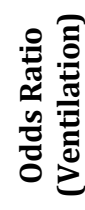 \\
\hline$\leq 20$ & $\begin{array}{c}60 \\
(60 \%)\end{array}$ & $6(6 \%)$ & $\begin{array}{c}\mathrm{P} \\
<0.001^{* *}\end{array}$ & 0.04 \\
\hline $21-25$ & $\begin{array}{c}16 \\
(16 \%)\end{array}$ & $6(6 \%)$ & $\mathrm{P}>0.005$ & 1.08 \\
\hline $26-30$ & $\begin{array}{c}18 \\
(18 \%)\end{array}$ & $18(18 \%)$ & $\begin{array}{c}\mathrm{P} \\
<0.001^{* *}\end{array}$ & - \\
\hline$>30$ & $6(6 \%)$ & $6(6 \%)$ & $0.0016^{*}$ & - \\
\hline \multicolumn{5}{|c|}{$\begin{array}{c}\text { Table 10: Relationship of Respiratory } \\
\text { Rate with Ventilation }\end{array}$} \\
\hline
\end{tabular}

$100 \%$ of the patients with respiratory rate $>25$ breaths/minute required ventilatory support, which is statistically significant with a $P$ value $<0.001$.

\begin{tabular}{|c|c|c|}
\hline $\begin{array}{c}\text { 02 Saturation } \\
\text { (n=100) }\end{array}$ & $\begin{array}{c}\text { Number of } \\
\text { Patients } \\
\text { Presented }\end{array}$ & $\begin{array}{c}\text { Number of } \\
\text { Patients with } \\
\text { Ventilation }\end{array}$ \\
\hline $90-100 \%$ & $62(62 \%)$ & - \\
\hline$\leq 89 \%$ & $38(38 \%)$ & $36(36 \%)$ \\
\hline \multicolumn{3}{|c|}{ Table 11: Relationship of O2 Saturation with } \\
Ventilation \\
\hline
\end{tabular}

Of the 38 patients who had oxygen saturation levels of $\leq 89 \%, 36(94.73 \%)$ required ventilatory support.

\begin{tabular}{|c|c|c|}
\hline $\begin{array}{c}\text { Accessory } \\
\text { Muscles }\end{array}$ & $\begin{array}{c}\text { Number of } \\
\text { Patients } \\
\text { Presented }\end{array}$ & $\begin{array}{c}\text { Number of Patients } \\
\text { with Ventilation }\end{array}$ \\
\hline Not-acting & $64(64 \%)$ & - \\
\hline In action & $36(36 \%)$ & $36(36 \%)$ \\
\hline \multicolumn{2}{|c|}{ Table 12: Relationship of the Use of Accessory } \\
Muscles with Ventilatory Support
\end{tabular}

$38(38 \%)$ patients had accessory muscles of respiration in action of which all required ventilatory support, this is statistically significant.

\begin{tabular}{|c|c|c|}
\hline \multirow{2}{*}{} & \multicolumn{2}{|c|}{ Atropine Dose (mg) within 48 hrs. } \\
\cline { 2 - 3 } & $\begin{array}{c}\text { Number of } \\
\text { Patients }\end{array}$ & Mean \pm SD \\
\hline Ventilated & 36 & $161.33 \pm 64.31$ \\
\hline Not ventilated & 64 & $100.93 \pm 93.12$ \\
\hline $\begin{array}{c}\text { Significance } \\
\text { Student t }\end{array}$ & \multicolumn{2}{|c|}{ Student t=3.971 P=0.00239** } \\
\hline $\begin{array}{c}\text { Table 13: Relationship of Atropine Dose within 48 Hours of } \\
\text { Admission with Ventilatory Support }\end{array}$ \\
\hline
\end{tabular}

Patients who were ventilated required a higher dose of atropine within 48 hours of admission as compared to those who were not ventilated. This is statistically significant.

\begin{tabular}{|c|c|c|c|c|}
\hline Factors & $\begin{array}{c}\text { No. of Patients } \\
\text { Ventilated }\end{array}$ & $\begin{array}{c}\text { No. of Patients not } \\
\text { Ventilated }\end{array}$ & P Values & $\begin{array}{c}\text { Odds Ratio } \\
\text { (Ventilation) }\end{array}$ \\
\hline Monocrotophos & $13(13 \%)$ & $13(13 \%)$ & 0.099 & 1.47 \\
\hline Chlorpyrifos & $13(13 \%)$ & $13(13 \%)$ & 0.099 & 1.47 \\
\hline Fasciculation score $(<3)$ & $16(16 \%)$ & $52(52 \%)$ & $0.0017^{* *}$ & 0.18 \\
\hline Fasciculation score $(\geq 4)$ & $20(20 \%)$ & $12(12 \%)$ & $0.0017^{* *}$ & 5.42 \\
\hline Pupil size $(\leq 1 \mathrm{~mm})$ & $20(20 \%)$ & $28(28 \%)$ & 0.3004 & 1.60 \\
\hline Pupil size $\geq 2 \mathrm{~mm}$ ) & $16(16 \%)$ & $36(36 \%)$ & 0.3004 & 0.62 \\
\hline GCS score $(\leq 10)$ & $22(22 \%)$ & $4(4 \%)$ & $\mathrm{P}<0.001^{* *}$ & 23.57 \\
\hline GCS score 11-15 & $14(14 \%)$ & $60(60 \%)$ & $\mathrm{P}<0.001^{* *}$ & 0.04 \\
\hline Mild poisoning & $10(10 \%)$ & $36(36 \%)$ & $0.007^{*}$ & 0.30 \\
\hline Mod. poisoning & $10(10 \%)$ & $20(20 \%)$ & 0.85 & 0.85 \\
\hline Severe poisoning & $16(16 \%)$ & $8(8 \%)$ & $0.0006^{*}$ & 5.60 \\
\hline Time lag $(<4$ hrs. $)$ & - & $4(4 \%)$ & $\mathrm{P}<0.001^{* *}$ & - \\
\hline Time lag ( $\geq 4$ hrs.) & $36(36 \%)$ & $60(60 \%)$ & $\mathrm{P}<0.001^{* *}$ & - \\
\hline Pulse rate $(\leq 60$ beats $/ \mathrm{min})$. & $2(2 \%)$ & $4(4 \%)$ & $\mathrm{P}>0.05$ & 0.88 \\
\hline Pulse rate ( $\geq 61$ beats/min.) & $34(34 \%)$ & $60(60 \%)$ & $\mathrm{P}>0.05$ & 1.13 \\
\hline $\begin{array}{c}\text { Respiratory rate } \\
(\leq 25 \text { breaths } / \mathrm{min})\end{array}$ & $12(12 \%)$ & $64(64 \%)$ & $\mathrm{P}<0.001^{* *}$ & - \\
\hline $\begin{array}{l}\text { Respiratory rate } \\
(>25 \text { breaths } / \mathrm{min})\end{array}$ & $24(24 \%)$ & - & $\mathrm{P}<0.001^{* *}$ & - \\
\hline 02 Saturation $(\leq 89 \%)$ & $36(36 \%)$ & $2(2 \%)$ & $\mathrm{P}<0.001^{* *}$ & - \\
\hline 02 Saturation $(>90)$ & - & 62 & $\mathrm{P}<0.001^{* *}$ & - \\
\hline Accessory muscles-In action & $36(36 \%)$ & - & $\mathrm{P}<0.001^{* *}$ & - \\
\hline Accessory muscles-not in action & - & $64(64 \%)$ & $\mathrm{P}<0.001^{* *}$ & - \\
\hline
\end{tabular}




\section{Statistical Methods}

Chi-square test and Fisher Exact test has been used to find the significance of ventilation requirement for all the study parameters. The odds ratio has been used to find the strength of relationship between the ventilation requirement and the each study parameters. Analysis of variance has been used to find the significance change of study parameters in mild, moderate, and severe type of poisoning. The Kruskal-Wallis test has been used to find the significance change of GCSscore in mild, moderate, and severe type of patients as the GCS score do not follow normal distribution. Student $t$ test has been used to find the significance of mean difference atropine within 48 hours between ventilated and not ventilated patients.

\section{Statistical Software}

The statistical software namely SPSS 10.0 and Systat 8.0 were used for the analysis of the data and Microsoft word and Excel have been used to generate.

\section{RESULTS}

Male patients were $60(60 \%)$ and females were $40(40 \%)$. The gender distribution among patients ventilated is not statistically significant with sex $(\mathrm{P}>0.05)$.

\section{DISCUSSION}

Acute organophosphorus compound poisoning is one of the most frequent poisonings encountered in M.G.M. Hospital. The major cause of poisoning in the present study was attempted suicides $(100 \%)$. Suicide is the major cause of poisoning in developing countries. ${ }^{7,11}$ In contrast figures from developed countries like Japan show accidental exposure forms a major bulk of organophosphorus compound poisoning cases. . $^{9,14}$

Among the 100 cases studied, majority of the patients were in the age group of 21-30 years (58\%). This correlates with the study done by S. Singh et al. ${ }^{15}$

In the present study, $60 \%$ of the patients were males. This correlates with the findings of the previous studies. However, in a study done by $M$. Vishwanathan et al, ${ }^{16} 66 \%$ of the patients who consumed organophosphorus compound were females.

Vomiting was the most common symptom in $80 \%$ of the patients in this study. This correlates with the studies done by OP Gupta et al,17 Sarjit Singh et al,18 and Goel et al ${ }^{19}$ where vomiting was present in $90 \%$ and $97.08 \%$ of the cases respectively. Vomiting was probably due to chemical gastritis.

Generalised fasciculations was another conspicuous feature in $72 \%$ of cases in this study. Whereas, studies done by Goel et al ${ }^{19}$ and Sarjit Singh et al ${ }^{20}$ showed that $55 \%$ and $100 \%$ of the patients respectively had fasciculations. Forty eight (48\%) patients had pupil size $\leq 1 \mathrm{~mm}$ of which 20 (41.6\%) patients required ventilatory support. According to the study done by OP Gupta et al $1728 \%$ had pupil size $\leq 1 \mathrm{~mm}$ who required ventilatory support. In comparison, in a study done by Robert et al ${ }^{18} 73 \%$ who had pupil size $\leq 1 \mathrm{~mm}$ required ventilation.

Bradycardia at admission was present in $6 \%$ of the cases in the present study. In comparison, in a study done by Robert et al, $2019 \%$ of the patients had bradycardia while in a study carried out by Semir Nouria ${ }^{21} 17 \%$ had bradycardia. This has not been compared with the need for ventilation.

Twenty four (24\%) patients had respiratory rate $>25$ breaths/min. of which all patients required ventilatory support. The higher respiratory rate was probably due to increased secretion and more severe respiratory paralysis caused by the poison itself. According to the study done by G. S. Mutalik et al, $1740 \%$ of the patients had a respiratory rate more than 30 breaths/min., but this has not been compared with the need for ventilation.

Thirty eight (38\%) patients had oxygen saturation levels of $\leq 89 \%$ out of which $36(94.73 \%)$ patients required ventilatory support. Thirty six (36\%) patients had accessory muscles of respiration in action of which all required ventilation. There are no comparative studies available.

It was observed in this study that $36 \%$ of the patient with respiratory failure required mechanical ventilation as compared to $40 \%$ of the patients in a study done by T.C. Tsao et al. ${ }^{11}$ Arterial blood gas analysis was done in 36 patients who had a respiratory rate $>25$ breaths/minute and whose accessory muscles of respiration were in action. All of them had respiratory acidosis.

Patients who were ventilated required a higher dose of atropine within 48 hours of admission as compared to those who were not ventilated. This was consistent with the findings of the study done by Goel et al. ${ }^{19}$ Higher dose of atropine may indirectly indicate the severity of poisoning, which might have caused respiratory paralysis requiring ventilation.

The severity of organophosphorus compound poisoning and the need for ventilatory support was studied in relationship to the nature of compounds consumed. $50 \%$ of the patients who consumed monocrotophos and $50 \%$ of the patients who consumed chlorpyrifos required ventilation in this study. Whereas, in the study done by Goel et al, $66.67 \%$ of the cases who had consumed dimethoate was associated with maximum need for ventilatory support. Ventilatory support was required by $84.6 \%$ of patients who had a GCS score level of less than 10 . This correlates very well with the study done by Goel et al ${ }^{19}$ where $84 \%$ of the patients with GCS score less than 10 required ventilation.

Of the patients with fasciculation score $\geq 4,62.5 \%$ required ventilatory support in our study whereas in a study done by Goel et al ${ }^{19} 55 \%$ of the patients with a fasciculation score of more than or equal to 4 required ventilatory support.

$21.7 \%$ of the patients with mild poisoning and $33.3 \%$ of the patients with moderate poisoning required ventilatory support. In contrast, $66.6 \%$ of the patients with severe poisoning required ventilation. Studies done by Goel et al 19 have shown that about $4 \%$ of the patients with mild and $6 \%$ of patients with moderate poisoning required ventilator support whereas $62 \%$ of the patients with severe poisoning required ventilatory support.

The reason for greater percentage of patients requiring ventilation in mild poisoning group in our study is likely to be due to the greater time lag between poison consumption and to admission at the hospital. This in turn resulted in delay in treatment like initiation of gastric lavage and administration of atropine and PAM.

Of the patients who were admitted to the hospital after 4 hours or more after consumption of organophosphorus poison, $36 \%$ required ventilator support as compared to those who were admitted within $<4$ hours of consumption. 
The studies done by Goel et al 64 and S.S. Kumar et al, which indicated a very significant relationship between delay in treatment and need for ventilator support. In contrast, a study done by Karnik et $\mathrm{al}^{22}$ found this delay statistically insignificant.

\section{CONCLUSION}

The factors which predicted the need for ventilatory support in organophosphorus compounds poisoning in our study of 100 patients were as follows:

1. The presence of higher fasciculation score $(\geq 4)$ was associated with the higher need for ventilatory support.

2. A GCS score $\leq 10$ was significantly associated with an increased need of ventilatory support.

3. Greater time lag between consumption of poison and admission to hospital ( $\geq 4$ hours) was associated with higher need for ventilator support.

4. Higher respiratory rate $(>25$ breaths/minute) and accessory muscles of respiration in action was significantly associated with higher need for ventilator support.

5. 02 saturation of $\leq 89 \mathrm{mmHg}$ was significantly associated with higher need for ventilatory support.

6. Grade 3 severity of poisoning was associated with higher need for ventilator support.

7. Dose of atropine greater than $150 \mathrm{mg}$ within 48 hours of admission was associated with higher need for ventilatory support.

8. The relationship between age group and sex with ventilatory support was not found to be significant.

9. Size of the pupil and pulse rate, type of organophosphorus compound consumed had no relevance in predicting the need for ventilatory support.

\section{REFERENCES}

1. Peter JV, Cherian AM. Organic insecticides. Anaesthesia and Intensive Care 2000;28(1):11-21.

2. Singh S, Sharma N. Neurological syndromes following organophosphate poisoning. Neurology India 2000;48(4):308-13.

3. Bardin PG, van Eeden SF, Moolman JA, et al. Organophosphorus and carbamate poisoning. Archives of Internal Medicine 1994;154(13):1433-41.

4. Singh S, Wig N, Chaudhary D, et al. Changing pattern of acute poisoning in adults: experience of a large North West Indian hospital (1970-1989). JAPI 1997;45(3): 194-7.

5. Malik GM, Mubarik M, Romshoo GJ. Organophosphorus poisoning in the Kashmir valley 1994 to 1997. NEJM 1998;338(15):1078.

6. Ferrando R. Pesticide poisoning in the Asia-Pacific region and the role of a regional information network. J Toxicol Clin Toxicol 1995;33(6):677-82.
7. Karalliedde L, Senanayake N. Organophosphorus insecticide poisoning. British Journal of Anaesthesia 1989;63(6):736-50.

8. Koelle GB. Pharmacology and toxicology of organophosphorus and carbamates. In: Ballantyn B, Marrs TC, eds. Clinical and experimental toxicology of organophosphates and carbamates. Oxford: Butterworth Heinemann 1992:33.

9. Namba T, Nolte CT, Jackrel J, et al. Poisoning due to organophosphate insecticide. American Journal of Medicine 1971;50(4):475-92.

10. Steward WC, Anderson EA. Effects of cholinesterase inhibition when injected into the medulla of the rabbit. Journal of Pharmacological Experimental Therapy 1968;162(2):309-18.

11. Tsao TC, Jwang Y, Lan RS, et al. Respiratory failure in acute organophosphorus and carbamate poisoning. Chest 1990;98(3):631-6.

12. Bardin $P G$, van Eeden SF, Joubert JR. Intensive care management of acute organophosphorus compound: a 7year experience in the West Cape. South African Medicine Journal 1987;72(9):593-7.

13. Bardin PG, Van Eeden SF. Organophosphorus poisoning: grading the severity and comparing treatment between atropine and glycopyrrolate. Critical Care Medicine 1990;18(9):956-60.

14. Mutalik GS, Wadia RS, Pai VR. Poisoning by diazinon an organophosphorus insecticide. Journal of Indian Medical Association 1962;38:67-71.

15. Singh S, Sharma BK, Chug KS. Spectrum of acute poisoning in adults (10 years' experience). JAPI 1984;32(7):561-3.

16. Vishwanathan M, Srinivasan K. Poisoning by bug poison. A preliminary study. Journal of Indian Medical Association 1962;39(7):345-9.

17. Gupta OP, Patel DD. Diazinon poisoning: a study of 60 cases. JAPI 1968;16(7):457-63.

18. Singh S, Balkrishan, Malhotra V. Parathion poisoning in Punjab (a clinical and electrocardiological study of 20 cases). JAPI 1969;17(3):181-7.

19. Goel A, Joseph S, Dutta TK. Organophosphate poisoning: predicting the need for ventilatory support. JAPI 1998;46(9):786-90.

20. Zwiener RJ, Ginsburg CM. Organophosphorus and carbamate poisoning in infants and children. Paediatrics 1988;81(1):121-6.

21. Nouria S, Abroug F, Elatrous S, et al. Prognostic value of serum cholinesterase in organophosphorus poisoning. Chest 1994;106(6):1811-4.

22. Karnik M, Ichaporia RN, Wadia RS. Cholinesterase levels in diazinon poisoning. I. Relation to severity of poisoning. JAPI 1970;18(3):337-44. 